\title{
Bone Sarcomas in Pediatrics: Progress in Our Understanding of Tumor Biology and Implications for Therapy
}

\author{
Rocio K. Rivera-Valentin ${ }^{1}$ - Limin Zhu ${ }^{1} \cdot$ Dennis P. M. Hughes ${ }^{1}$
}

Published online: 23 May 2015

(C) The Author(s) 2015. This article is published with open access at Springerlink.com

\begin{abstract}
The pediatric bone sarcomas osteosarcoma and Ewing sarcoma represent a tremendous challenge for the clinician. Though less common than acute lymphoblastic leukemia or brain tumors, these aggressive cancers account for a disproportionate amount of the cancer morbidity and mortality in children, and have seen few advances in survival in the past decade, despite many large, complicated, and expensive trials of various chemotherapy combinations. To improve the outcomes of children with bone sarcomas, a better understanding of the biology of these cancers is needed, together with informed use of targeted therapies that exploit the unique biology of each disease. Here we summarize the current state of knowledge regarding the contribution of receptor tyrosine kinases, intracellular signaling pathways, bone biology and physiology, the immune system, and the tumor microenvironment in promoting and maintaining the malignant phenotype. These observations are coupled with a review of the therapies that target each of these mechanisms, focusing on recent or ongoing clinical trials if such information is available. It is our hope that, by better understanding the biology of osteosarcoma and Ewing sarcoma, rational combination therapies can be designed and systematically tested, leading to improved outcomes for a group of children who desperately need them.
\end{abstract}

Dennis P. M. Hughes

dphughes@mdanderson.org

1 Department of Pediatrics-Research, The Children's Cancer Hospital at MD Anderson Cancer Center, Unit 853, MOD $1.021 \mathrm{~d}, 1515$ Holcombe Blvd, Houston, TX 77030, USA

\section{Key Points}

Many of the therapeutic targets important in common adult cancers are also important for osteosarcoma and Ewing sarcoma.

Preclinical and early clinical trial data are available to support the use of many of these agents in children.

Combination therapy has generally been safe in children and should be evaluated further with more agents.

\section{Introduction}

Osteosarcoma (OS) is the most common type of primary bone cancer [1], occurring primarily in adolescents and young adults, with a peak incidence in the second decade of life. Standard therapy consists of surgical removal of any resectable primary tumor and metastases, combined with 6-9 months of neoadjuvant and adjuvant chemotherapy [2]. Current chemotherapy regimens include four agents: doxorubicin (adriamycin), cisplatin, and high-dose methotrexate with leukovorin rescue [3-5]. Some clinicians have used ifosfamide for patients with high-risk or metastatic disease [6], though the recently completed EURAMOS (European and American Osteosarcoma Study) showed definitively that the addition of ifosfamide to adjuvant MAP (methotrexate, doxorubicin [adriamycin], and cisplatin) chemotherapy for OS patients with poor necrosis increased toxicity without improving survival (results presented at the annual meeting of the Connective 
Tissue Oncology Society Annual Meeting, Berlin, Germany, 2014). Although modern multimodal therapy yields $70 \%$ survival for patients without overt metastasis at diagnosis, outcome for metastatic OS remains poor: fewer than $30 \%$ of patients presenting with metastases survive 5 years after diagnosis [7].

Ewing sarcoma (ES) is the second most common bone malignancy. It is characterized typically by a translocation between chromosomes 22 and 11, generating a fusion between the EWS and FLII genes [8]. ES occurs through a broad age range, from infants to older adults, with a peak incidence in the second decade of life and a slightly higher incidence rate in males $[9,10]$. ES arises most frequently in bones, but occasionally develops in soft tissues [11]. Intensive multimodal treatment with combination chemotherapy, surgery, and radiation has increased the overall survival rate from less than $10 \%$ to around $50 \%$ [12-15]. The current standard of care for newly diagnosed ES consists of chemotherapy with five drugs: vincristine/doxorubicin/cyclophosphamide alternating with ifosfamide and etoposide [16, 17]. Standard therapy should include 17 cycles of chemotherapy, though 'good-risk' patients with localized disease in an extremity may be safely reduced to 14 cycles. Chemotherapy cycles should be compressed to every 2 weeks rather than every 3 in those patients who can tolerate it-typically younger patients-as compressed timing has a proven survival advantage [18].

While intensive multi-agent chemotherapy has improved survival compared with the pre-chemotherapy era, there have been few recent improvements in outcome for either non-metastatic patients or those who present with metastatic disease, and it has been difficult even for therapies that prove beneficial, such as mifamurtide [19], to obtain regulatory approval. However, in recent years, great advances have been made in understanding the molecular basis of pathogenesis and progression of pediatric bone sarcomas. This new understanding has been achieved in parallel with an explosion of novel therapies developed specifically to inhibit cancer-associated genes and pathways. Identification of key regulatory pathways and molecular biomarkers yielded dramatic changes in outcome for several adult cancers, but childhood cancer, and bone sarcomas in particular, have largely been sidelined in this revolution.

To help make these important discoveries relevant for childhood bone sarcomas, it is important to have an understanding of the role of each signaling pathway in the biology of the disease, as well as the available agents that target these processes. Priority was given to those pathways for which there is good information about the relevance to OS or ES, and those agents for which data are available. Where possible, we describe the reported results of clinical trials completed with novel therapies, especially highlighting those that involve children or are specific for bone sarcoma.
We highlight the studies that we have been able to identify that use targeted therapy for bone sarcoma, whether for children or adults, since some treating physicians may choose to apply knowledge gained from these adult studies to their care of children with similar conditions. We have also included the results of some novel therapies that have been proven ineffective in clinical trials. To provide coherence to this broad topic, we have organized this review into sections highlighting processes at the plasma membrane, intracellular signaling pathways, bone metabolism, and the environmental and immune interactions of bone sarcoma.

\section{Surface Markers for Osteosarcoma (OS): Receptor Tyrosine Kinases}

Receptor tyrosine kinases (RTKs) are cell-surface proteins that act as receptors for various extracellular ligands, including growth factors, hormones, and cytokines. In addition to regulating normal cellular processes, RTKs and the intracellular signaling pathways they activate are critical to oncogenesis for many types of cancer [20]. Deregulation of a variety of RTKs, including insulin-like growth factor receptor type I (IGF-1R), vascular endothelial growth factor receptor (VEGFR), human epidermal growth factor receptor 2 (HER2, also called ERBB2), and plateletderived growth factor receptor (PDGFR), have been implicated in pediatric bone sarcomas [21, 22]. Note that, because of the biology of the process affected, VEGFR inhibition is discussed in the environmental interactions section, rather than with RTKs, since the target tissue affected by these agents is the tumor vasculature rather than the tumor cells themselves. Since RTKs were the first molecular targets attacked in the current wave of small molecule therapeutics, with the greatest range of drugs approved or in development, each of the RTK pathways relevant to OS and ES biology is considered below.

\subsection{Insulin-Like Growth Factor Receptor Type I (IGF-1R)}

IGF-1R mediates cell differentiation, proliferation, and apoptosis in human cancer by activating two major oncogenic signaling cascades: the phosphoinositide 3-kinase (PI3K) pathway and the mitogen-activated protein kinase (MAPK) pathway [23, 24]. Elevated expression of IGF-1R has been observed in most OS and ES cell lines and tumor samples [25-27]. Overexpression of IGF-1R and its ligand IGF-1 in pediatric bone sarcomas is correlated with a poorer prognosis, and IGF pathway inhibition impeded tumor growth and metastasis in preclinical models [28, 29].

Current therapeutic approaches directed against the IGF$1 \mathrm{R}$ pathway can be grouped into three categories: 
monoclonal antibodies targeting IGF-1R, IGF ligand-neutralizing antibodies, and small-molecule tyrosine kinase inhibitors. At present, eight different anti-IGF-1R monoclonal antibodies (mAbs) have been or are currently being evaluated in phase I/II clinical trials, and one of which is being evaluated in pediatric patients (Table 1). Although their safety has been proven in pediatric patients, these IGF-1R antagonists displayed limited or no clinical benefit as monotherapy for patients with advanced bone sarcomas [30-37]. Investigations using IGF-1R-targeted agents in combination are ongoing, though it is not clear what benefit these studies will show. Further, since these agents showed no benefit in common adult malignancies, their development has been abandoned by the pharmaceutical industry, suggesting that they are unlikely to be available for future bone sarcoma patients.

An alternative approach to inhibit IGF signaling is to neutralize the bioactivity of IGF ligands IGF-I and -II with mAbs. In preclinical studies, these agents achieved more effective inhibition of IGF signaling than IGF-1R mAbs by blocking binding of IGF-I and -II ligands to IGF-1R and insulin receptor (IR)-A [38, 39]. Two neutralizing antibodies against IGF-I/II are available: MEDI-573 and BI836845. A phase I clinical trial for MEDI-573 in adult patients with advanced solid tumors demonstrated stable disease in 13 of 39 patients [40]. Currently, five phase I clinical trials of BI836845 are ongoing in adult patients with various solid tumors, but there have been no specific studies in OS or ES patients. Since IGF-II and IGF-2R can also be overexpressed in OS and ES, these patients might benefit from therapies that target both IGF ligands [27, 41].

In addition to mAbs, small-molecule inhibitors of IGF$1 \mathrm{R}$ are also being developed. Some of these agents also inhibit IR-A-dependent tumor growth [42]. Novel IGF-1R tyrosine kinase inhibitors include linsitinib, XL-228, INSM-18, GSK1904529A, GSK1838705A, and BMS554417 , all of which have shown promising results in pediatric sarcoma models during preclinical studies [22]. As yet, no pediatric clinical trial data have been reported for these agents.

\subsection{Human Epidermal Growth Factor Receptor 2 (HER2) and the ERBB Family}

HER2 is one of the four RTKs in the epidermal growth factor receptor (HER/EGFR/ERBB) family and has an essential role in tumor growth. In recent years, targeted therapies against HER2 have achieved significant therapeutic benefits in the treatment of several solid tumors. However, data have been conflicting regarding expression of HER2 in OS and ES and its association with clinical outcome. While some reports demonstrated minimal expression of HER2 in tumor samples of pediatric bone sarcomas or lack of correlation between HER2 expression level and patient outcome [43-48], other studies have suggested that HER2 is highly expressed in up to $40 \%$ of OS cases and $20 \%$ of ES cases and its overexpression is correlated with metastases and poor prognosis [46, 49-55]. One possible reason for these disparate results may be purely technical: the Her-2 antigen is susceptible to oxidative degradation, such that it is essentially undetectable 6 months after slides are cut $[56,57]$. The safety of the HER $2 \mathrm{mAb}$ trastuzumab in combination with standard chemotherapy has been shown in a phase II clinical trial for OS, but no benefit was seen [58]. There is no clear evidence of therapeutic benefit for this agent in bone sarcoma, and no basis for treating bone sarcoma patients with it except in the context of a clinical trial. In addition to the antibody approach, small-molecule tyrosine kinase inhibitors of the ERBB family such as erlotinib, lapatinib, afatinib, neratinib and dacomitinib are currently in clinical development [59]. Since HER4, another member of the HER family, has emerged in recent years as an essential regulator in OS, ES, and other pediatric solid tumors [6062], the pan-Her small-molecule inhibitors (afatinib, dacomitinib, and neratinib) may represent a more effective approach in treating pediatric bone sarcomas than EGFRspecific small-molecule inhibitors such as erlotinib [63, 64].

\subsection{Platelet-Derived Growth Factor Receptor (PDGFR)}

The PDGF family of signaling molecules consists of five ligands (PDGF-AA, -BB, -AB, -CC, -DD), and two RTKs (PDGFR- $\alpha$ and $-\beta$ ) [65]. In OS and ES, PDGF/PDGFR signaling has a central role in tumor growth and metastasis, and overexpression of PDGFR- $\alpha$ and $-\beta$ is often correlated with poor prognosis [66-69]. Imatinib, a potent inhibitor of c-Kit and PDGFR, has been evaluated in phase II clinical trials for treating bone sarcomas. However, this compound failed to demonstrate significant antitumor activity as a single agent in children with recurrent OS and ES [70, 71]. Since blocking PDGF/PDGFR signaling is not sufficient to inhibit tumor progression in patients, other multi-targeted RTK inhibitors such as dasatinib are currently being studied in phase I/II studies for patients with advanced sarcomas (Table 1).

\section{Intracellular Signaling Pathways}

Cellular signaling is a complex process by which extracellular events alter intracellular physiology and gene expression. While there is a great diversity of transmembrane receptors and other agents that can initiate signaling, 
Table 1 Active clinical trials in osteosarcoma and Ewing sarcoma [180-183]

\begin{tabular}{|c|c|c|c|c|}
\hline Target & Class & Drug & Clinical trial & Age (y) \\
\hline IGF-1R & Anti-IGF-1R antibodies & Cixutumumab with temsirolimus & $\begin{array}{l}\text { Phase II: Recurrent or refractory solid tumors in } \\
\text { pediatric patients (NCT01614795) }\end{array}$ & $>1$ to 30 \\
\hline \multirow[t]{8}{*}{ VEGF/VEGFR } & \multirow[t]{2}{*}{ Anti-VEGF antibodies } & Bevacizumab with chemotherapy & Phase II: OS (NCT00667342) [180] & Up to 30 \\
\hline & & Bevacizumab with chemotherapy & $\begin{array}{l}\text { Phase II: ES family of tumor and desmoplastic } \\
\text { small round cell tumors (NCT01610570) }\end{array}$ & $>1$ \\
\hline & VEGF inhibitors & $\begin{array}{l}\text { Endostar (recombinant human } \\
\text { endostatin) with chemotherapy }\end{array}$ & Phase II: OS (NCT01002092) & $12-60$ \\
\hline & \multirow[t]{5}{*}{ Small-molecule TKIs } & Pazopanib & $\begin{array}{l}\text { Phase II: OS metastatic to the lung } \\
\text { (NCT01759303) }\end{array}$ & $>60$ \\
\hline & & Pazopanib & $\begin{array}{l}\text { Phase II: Refractory solid tumors in children, } \\
\text { adolescents, and young adults (NCT01956669) }\end{array}$ & $>1$ to 18 \\
\hline & & Regorafenib & $\begin{array}{l}\text { Phase II: Refractory liposarcoma, OS, and ES } \\
\text { (NCT02048371) }\end{array}$ & $>18$ \\
\hline & & Sorafenib with irinotecan & $\begin{array}{l}\text { Phase I: Relapsed or refractory solid tumors in } \\
\text { pediatric patients (NCT01518413) }\end{array}$ & $2-22$ \\
\hline & & Sorafenib with everolimus & $\begin{array}{l}\text { Phase II: Relapsed and non-resectable high-grade } \\
\text { OS (NCT01804374) [181] }\end{array}$ & $>18$ \\
\hline \multirow[t]{3}{*}{ PDGFR } & \multirow[t]{3}{*}{ Small-molecule TKIs } & Imatinib mesylate & $\begin{array}{l}\text { Phase II: Refractory or relapsed solid tumors in } \\
\text { children (NCT00030667) }\end{array}$ & Up to 30 \\
\hline & & Dasatinib & $\begin{array}{l}\text { Phase II: Advanced sarcomas including ES } \\
\text { (NCT00464620) }\end{array}$ & $>13$ \\
\hline & & Dasatinib with ipilimumab & $\begin{array}{l}\text { Phase I: Advanced sarcomas including OS and ES } \\
\text { (NCT01643278) }\end{array}$ & $>18$ \\
\hline \multirow[t]{3}{*}{ HDACi } & \multirow{3}{*}{$\begin{array}{l}\text { Small-molecule } \\
\text { inhibitors of histone } \\
\text { deacetylase }\end{array}$} & $\begin{array}{l}\text { Vorinostat, docetaxel, and } \\
\text { gemcitabine }\end{array}$ & Phase Ib/II: Advanced sarcoma & $>18$ \\
\hline & & Vorinostat and etoposide & Phase I/II: Relapsed/refractory sarcomas & $<4$ to 21 \\
\hline & & $\begin{array}{l}\text { Valproic acid and bevacizumab } \\
\text { with gemcitabine and docetaxel }\end{array}$ & $\begin{array}{l}\text { Phase I/II: Locally advanced, unresectable or } \\
\text { metastatic sarcoma (NCT01106872) Note: this } \\
\text { is a combination of HDACi with VEGF } \\
\text { inhibition }\end{array}$ & $>18$ \\
\hline \multirow[t]{5}{*}{ Bone metabolism } & \multirow[t]{3}{*}{ Bisphosphonates } & $\begin{array}{l}\text { Zoledronic acid/zoledronic acid } \\
\text { with 'standard chemotherapy' }\end{array}$ & Phase II/III: High-grade OS (NCT00691236) & $18-65$ \\
\hline & & $\begin{array}{l}\text { Zoledronic acid with } \\
\text { chemotherapy }\end{array}$ & Phase III: High-grade OS (NCT00470223) & $5-50$ \\
\hline & & Zoledronic acid with busulfan & $\begin{array}{l}\text { Phase III: Localized and disseminated ES } \\
\text { (NCT00987636) }\end{array}$ & $4-50$ \\
\hline & \multirow[t]{2}{*}{$\begin{array}{l}\text { Conjugated } \\
\text { radioisotopes }\end{array}$} & $\begin{array}{l}\text { 153SM-EDTMP with external } \\
\text { beam radiotherapy }\end{array}$ & Phase II: High-risk OS (NCT01886105) & $13-65$ \\
\hline & & Radium-223 dichloride & Phase I/II: High-risk OS (NCT01833520) & $>15$ \\
\hline \multirow[t]{3}{*}{ mTOR } & \multirow[t]{3}{*}{$\begin{array}{l}\text { Small-molecule } \\
\text { inhibitors }\end{array}$} & Everolimus & $\begin{array}{l}\text { Phase II: Refractory or relapsed OS } \\
\text { (NCT01216826) }\end{array}$ & Up to 21 \\
\hline & & Sirolimus with chemotherapy & $\begin{array}{l}\text { Phase I: Recurrent and refractory solid tumors in } \\
\text { children (NCT01331135) }\end{array}$ & Up to 30 \\
\hline & & $\begin{array}{l}\text { Sirolimus with } \\
\text { cyclophosphamide }\end{array}$ & $\begin{array}{l}\text { Phase II: Advanced sarcomas including OS and } \\
\text { ES (NCT00743509) }\end{array}$ & $>16$ \\
\hline Notch & $\begin{array}{l}\text { Gamma secretase } \\
\text { inhibitors }\end{array}$ & RO4929097 with vismodegib & $\begin{array}{l}\text { Phase I/II: Advanced or metastatic sarcoma } \\
\text { including OS and ES (NCT01154452) }\end{array}$ & $>18$ \\
\hline Hedgehog & $\begin{array}{l}\text { Hedgehog signaling } \\
\text { antagonists }\end{array}$ & Vismodegib with RO4929097 & See above & $>18$ \\
\hline Src & $\begin{array}{l}\text { Small-molecule } \\
\text { inhibitors }\end{array}$ & Saracatinib & $\begin{array}{l}\text { Phase II: Recurrent OS localized to the lung } \\
\text { (NCT00752206) }\end{array}$ & $15-74$ \\
\hline
\end{tabular}


Table 1 continued

\begin{tabular}{|c|c|c|c|c|}
\hline Target & Class & Drug & Clinical trial & Age (y) \\
\hline \multirow[t]{4}{*}{ PARP } & \multirow[t]{4}{*}{$\begin{array}{l}\text { PARP inhibitors/ } \\
\text { alkylating agents }\end{array}$} & Olaparib with temozolomide & $\begin{array}{l}\text { Phase I: Recurrent or metastatic ES following } \\
\text { failure of prior chemotherapy (NCT01858168) }\end{array}$ & $>18$ \\
\hline & & Olaparib & $\begin{array}{l}\text { Phase II: Recurrent of metastatic ES following } \\
\text { failure of prior chemotherapy (NCT01583543) } \\
\text { [182] }\end{array}$ & $>18$ \\
\hline & & Niraparib with temozolomide & $\begin{array}{l}\text { Phase I: Previously treated, incurable ES } \\
\text { (NCT02044120) }\end{array}$ & $>13$ \\
\hline & & BMN-673 with temozolomide & $\begin{array}{l}\text { Phase I/II: Refractory or recurrent malignancies } \\
\text { including ES in younger patients } \\
\text { (NCT02116777) }\end{array}$ & $13-30$ \\
\hline \multirow[t]{5}{*}{ Immunotherapy } & Interferons & $\begin{array}{l}\text { Low-dose IFN } \alpha \text {-2b with } \\
\text { thalidomide }\end{array}$ & $\begin{array}{l}\text { Phase II: Soft tissue sarcoma or bone sarcoma } \\
\text { (NCT00026416) }\end{array}$ & $>18$ \\
\hline & Immunostimulants & Aerosol IL-2 & $\begin{array}{l}\text { Phase I/II: Pulmonary metastases of solid tumors } \\
\text { including OS and ES (NCT01590069) }\end{array}$ & $12-50$ \\
\hline & \multirow[t]{3}{*}{ GD2-based therapies } & $\begin{array}{l}\text { Activated T cells armed with } \\
\text { GD2-bispecific antibody }\end{array}$ & $\begin{array}{l}\text { Phase I/II: OS and neuroblastoma in children and } \\
\text { young adults (NCT02173093) }\end{array}$ & $>1$ to 29 \\
\hline & & $\begin{array}{l}\text { Humanized anti-GD2 antibody } \\
\text { (HU14.18K233A) }\end{array}$ & $\begin{array}{l}\text { Phase I: OS and ES in children and adolescents } \\
\text { (NCT00743496) [183] }\end{array}$ & Up to 21 \\
\hline & & $\begin{array}{l}\mathrm{T} \text { cells expressing an anti-GD2 } \\
\text { chimeric antigen receptor }\end{array}$ & $\begin{array}{l}\text { Phase I: GD2+ solid tumors in children and young } \\
\text { adults (NCT02107963) }\end{array}$ & $1-35$ \\
\hline
\end{tabular}

$E S$ Ewing sarcoma, $H D A C i$ histone deacetylase inhibitor, $I F N$ interferon, $I G F-1 R$ insulin-like growth factor receptor type $1, I L$ interleukin, mTOR mammalian target of rapamycin, $O S$ osteosarcoma, $P A R P$ poly ADP ribose polymerase, $P D G F R$ platelet-derived growth factor receptor, $S r c$ steroid receptor co-activator, TKIs tyrosine kinase inhibitors, VEGF vascular endothelial growth factor, VEGFR VEGF receptor, $y$ years

common pathways often are used by diverse receptors, and therapeutic approaches have been developed to attack the most vital pathways in cancer. In recent years, there have been many advances in our understanding of how these pathways function in OS and ES, and which are essential for the cancer cell. The intracellular signaling pathways important for OS and ES are discussed here.

\subsection{Ezrin}

As a member of the ezrin/radixin/moesin (ERM) family, ezrin links the actin cytoskeleton to the plasma membrane. Gene microarray studies demonstrated increased Ezrin expression in metastatic OS lesions [72]. Further, high ezrin expression in OS patients, both human and canine, was correlated with poor overall survival $[72,73]$. Khanna and colleagues $[73,74]$ demonstrated that early steps in OS pulmonary metastases are dependent on ezrin-mediated protein kinase B (AKT) and MAPK signaling, and reduction of ezrin expression by a short hairpin RNA (shRNA) decreased the survival of metastatic cells in the lung. The relevance of ezrin in metastatic disease has been validated for other sarcomas, including ES, although in this model ezrin mediates metastasis by signaling through the AKT/mammalian target of rapamycin (mTOR) pathway [75]. Two small-molecule ezrin inhibitors have been successfully studied in vitro and in vivo using OS models, but these agents still await testing in clinical trials [76].

\subsection{Mammalian Target of Rapamycin (mTOR)}

The mTOR is a serine/threonine kinase and integral effector of the PI3K-AKT signaling pathway. It regulates cell cycle progression and protein synthesis among other steps during carcinogenesis [77]. Rapamycin (sirolimus) and its derivatives have been effective at reducing tumor growth in OS and ES murine models and in clinical trials [78-82] and has been used as a radiosensitizer for OS [83]. A recent phase III clinical trial tested ridaforolimus in adult sarcoma patients who had achieved objective responses with prior chemotherapy [84]. For the 702 patients treated on that study (only $10 \%$ had bone sarcoma), ridaforolimus increased progression-free survival by $28 \%(p<0.001)$, but greatly increased grade 3 or higher toxicities, especially stomatitis, cytopenias, and infection. The report does not provide a subset analysis for the bone sarcoma patients. Several clinical trials using mTOR inhibitors in combination therapies are in progress (Table 1).

\subsection{Steroid Receptor Co-Activator (Src)}

The steroid receptor co-activator ( $\mathrm{Src}$ ) family of kinases is expressed at high levels and is constitutively active in many cancers, including OS and ES. Pharmacologic inhibition of Src in vitro led to apoptosis and decreased invasion, migration, and adhesion of OS and ES cells; however, these results were not reproducible using OS in vivo 
models, pointing at possible redundancy in activation of downstream effectors like focal adhesion kinase (FAK) [85-88]. A dual inhibitor of BCR-Abl and Src, dasatinib has been used in one clinical trial where the maximum tolerated dose was determined but no objective responses were observed [89]. Clinical trials are in progress with either dasatinib alone or in combination therapy or with saracatinib, an Src-specific inhibitor.

\subsection{Notch}

Signaling via the Notch pathway is essential for the development of most organ systems, including for both neurogenesis [90] and osteoblast maturation [91]. Activation of the Notch pathway is required for vasculogenesis during tumor progression in ES [92]. Notch has been linked to increased invasion and metastasis in OS, in part through promoting a tumor-initiating cell phenotype [93-95]. Membrane-bound Notch activation upon ligand binding occurs through a twostep proteolytic process carried by ADAMs family proteases followed by gamma-secretase cleavage, releasing a soluble intracellular Notch that can regulate transcription [96]. A phase I clinical trial in advanced solid malignancies using a gamma-secretase inhibitor (GSI) showed anti-tumor activity and a low toxicity profile [97]. A phase I/II clinical trial using a GSI in combination with an inhibitor of the hedgehog pathway for the treatment of metastatic sarcomas is currently recruiting patients. In considering the effects of GSI, one should recall that GSIs inhibit the processing of several receptors that effect metastasis, including Her-4, CD44, E-cadherin, and N-cadherin [98].

\subsection{Hedgehog}

The hedgehog pathway is important for embryonic development and is dysregulated in various cancers. High expression of the hedgehog ligands and targets are observed in both OS and ES models, where this pathway is activated in both a ligand-dependent and a ligand-independent manner [99-101]. Interestingly, EWS-FLI1 signaling is mediated through GLI, an effector and transcription regulator in the hedgehog pathway [102]. Inhibition of the hedgehog pathway in vitro and in ES and OS xenografts has been successful and warrants further research [100, 103]. In a recent clinical trial in adult patients with advanced solid tumors, an oral inhibitor of the hedgehog pathway was fairly well tolerated [104]. While the skeletal abnormalities seen in young mice briefly treated with hedgehog pathway inhibitors might raise concerns about pediatric applications for these agents [105], most OS and ES patients are close to their expected adult size at diagnosis, suggesting that these concerns should not preclude study.

\subsection{Histone Deacetylase Inhibitors}

Histone deacetylase inhibitors (HDACi) have been studied in cancer due to their effects in promoting transcription of tumor suppressor genes silenced during malignant transformation. Phase I clinical trials in pediatric patients with relapsed or refractory solid tumors using pracinostat or vorinostat monotherapy showed no tumor responses [106, 107]. Patient trials are underway using combination therapy with HDACi and adjuvant chemotherapies and may have greater promise (Table 1). Additionally, treatment with HDACi in preclinical models caused upregulation of natural killer (NK) cell recognition markers and of the apoptosis-promoting Fas receptor, resulting in increased sensitivity to NK-mediated killing [108, 109]. These results warrant further investigation in clinical trials of $\mathrm{HDACi}$ plus NK cells.

\subsection{Ras}

Ras proteins are small GTPases that regulate cell proliferation, apoptosis, and survival by activating multiple downstream signaling pathways, including MAPK. Though constitutively active, Ras mutations are uncommon in pediatric sarcomas; targeting Ras reduced tumor growth, possibly due to the many pathways requiring Ras relay signals [110-113]. Reolysin is an oncolytic virus that selectively targets Ras transformed cells, and xenografts showed tumor growth inhibition by reolysin used alone or with chemotherapy agents [114]. A phase II study in sarcoma patients has been completed. While partial results were presented at the American Society of Clinical Oncology (ASCO) annual meeting in 2009 [115], there have been no peer-reviewed publications for sarcoma since that abstract was presented.

\subsection{MDM2}

MDM2 is a ubiquitin ligase that regulates p53 activity by targeting this tumor suppressor for proteasomal degradation. Nutlins are small molecules that inhibit MDM2 and p53 binding, leading to increased availability of p53. Treatment using nutlins have been effective in OS and ES models, inducing apoptosis and cell cycle arrest [116-118]. RG7112, a nutlin family member, induced tumor regression in ES models, but no objective response was observed with OS models [119]. Recently, a phase I clinical trial using RG7112 in patients with relapsed or refractory tumors was completed, though results have yet to be reported. 


\section{Targeting Bone Metabolism}

Tumor growth and metastasis often require constant interactions between tumor cells and their surrounding microenvironments [54, 120-123]. Therapeutic agents that target the bone environment and modulate bone metabolism have demonstrated some efficacy in pediatric bone sarcomas.

\subsection{Bisphosphonates}

Bisphosphonates, which inhibit the mevalonate pathway at high concentrations and impede osteoclast-mediated bone resorption through induction of osteoclast apoptosis, have been shown to suppress tumor growth and pulmonary metastasis of ES in preclinical models [124-128]. To date, several types of bisphosphonates, including zoledronate, pamidronate, and alendronate, displayed significant antitumor activity in vitro and in vivo [129-132]. A phase II study evaluating the combination of chemotherapy and pamidronate for patients with OS demonstrated little impact on patient survival [133]. However, pamidronate has been shown to improve the durability of limb reconstruction [133]. In a recently completed phase I study, the addition of zoledronate to conventional multi-agent chemotherapy was safe but failed to demonstrate statistically significant differences in event-free or overall survival in patients with newly diagnosed metastatic OS [134]. However, our clinical team has treated many patients with bone metastasis of OS with zoledronate, and we have found that patients usually do not develop new bone metastases after receiving four to six doses of monthly zoledronate. We also have the impression that the need for opiates during palliation is reduced after patients receive bisphosphonates, suggesting that the clinical trials performed to date may not have looked at the correct endpoints. Currently, three phase II/III trials that evaluate the efficacy of zoledronate as a single agent or as an adjuvant to chemotherapy in localized and metastatic OS and ES are ongoing (Table 1).

\subsection{Conjugated Radioisotopes}

Conjugated radioisotopes such as Samarium $\left({ }^{153} \mathrm{Sm}\right)$ lexidronam (Samarium-153 EDTMP) and radium-223 dichloride (Xofigo) have high specificity for bone uptake, which allows for the local delivery of high-dose radiation in bone tumors [135, 136]. Standard dose of Samarium-153 EDTMP was originally approved by the US FDA for pain management in patients with bone metastases, and radium223 was recently approved for the treatment of castrationresistant prostate cancer patients with symptomatic bone metastases. Although radiation therapy is not widely used in treatment for OS, high-dose conjugated radioisotopes are under clinical investigation for their anti-tumor activities against OS. In a follow-up study of 14 patients with osteoblastic OS, Samarium-153 EDTMP in combination with the radiosensitizer gemcitabine induced short-term antitumor response in eight patients [137]. Thus far, conjugated radioisotopes have no clear role in Ewing sarcoma. The ongoing clinical trials for this class of agents include a phase I/II study for radium-223 dichloride and a phase II study for Samarium-153 EDTMP in combination with external radiotherapy in high-risk OS (Table 1).

\subsection{Denosumab}

Among the signaling molecules that have been associated with worse outcome in OS is the receptor activator of nuclear factor-kb (RANK), along with its ligand (RANKL) and decoy osteoprotegerin (OPG), which normally are essential for regulation of the homeostasis between bone lysis and formation during bone remodeling [138, 139]. High expression of RANKL is associated with reduced survival in OS [140], and some OS cell lines have functional RANK expression [141], allowing for possible autocrine stimulation of this pathway. Inhibition of RANK with shRNA reduced motility and anoikis resistance in OS cell lines, while overexpression of RANK using a retroviral vector increased OS cell motility without affecting proliferation [142].

Denosumab is an mAb specific for human RANKL and was developed initially to treat osteoporosis [143] and was later found effective in treating painful bone metastasis [144-147]. It was subsequently found to be an effective treatment for giant cell tumor of bone [148], a benign but destructive neoplasm in which transformed mononuclear cells secrete RANKL, causing osteoclast hyperactivity. We have found that denosumab can be effective in treating painful bone metastasis in OS, which is in line with the FDA-approved indication for the drug. Whether it will have any direct effect against OS in patients remains to be seen.

\section{Environmental and Immune Interactions of Bone Sarcoma}

While initial studies of cancer biology took a purely cellautonomous view of the cancer problem and sought to understand and then target the specific biology of the malignant cell, it is now abundantly clear that all cancers, including bone sarcomas, exist in a complex environment of non-malignant supporting cells like fibroblasts and endothelial cells, non-cellular stromal elements and matrix 
proteins, and cellular and protein components of the innate and adaptive immune system [149]. While malignant cells may become resistant to conventional chemotherapy, they still must evade the immune system and continue to recruit a blood supply and engage their environment for tumors to grow and spread [150]. Recent developments seek to better understand these interactions and exploit them for therapy.

\subsection{Immunotherapy}

\subsubsection{Mifamurtide}

Muramyl tripeptide phosphatidyl ethanolamine (L-MTP$\mathrm{PE}$ or mifamurtide) is a synthetic peptide derived from the cell wall of the Bacille Calmette-Guerin mycobacterium that has potent immunostimulatory properties [151]. Liposomal encapsulation of MTP-PE with phospholipids that include phosphatidyl serine specifically triggers uptake into macrophages and monocytes [152], which then become activated, increasing phagocytosis and secreting interleukin (IL)-6, tumor necrosis factor (TNF)- $\alpha$ and other cytokines $[19,151,153]$. A phase III clinical trial concluded that addition of mifamurtide to standard chemotherapy leads to an increase in the 6-year overall survival in primary OS patients from 70 to $78 \%$ [19]. Mifamurtide has been approved as an adjuvant for the treatment of primary OS in Europe, Israel, Japan, and Mexico, among other places, but has not been approved by the US FDA [151, 153, 154].

\subsubsection{Sargramostim}

Sargramostim, the granulocyte macrophage colony-stimulating factor (GM-CSF) is an immune modulator that promotes the activation and recruitment of neutrophils, monocytes, and other immune cells [155]. Promising in vitro and in vivo preclinical studies with sargramostim prompted a phase I clinical trial of inhaled sargramostim, which demonstrated low toxicity [156-158]. However, a phase II clinical trial did not show any survival benefit compared with standard treatment regimes in OS and ES patients $[159,160]$.

\subsubsection{Other Immunomodulators}

Conflicting results have been observed using interferon (IFN)- $\alpha$ for OS treatment. Despite some promising early studies [161], the good responder arm of the EURAMOS 1 trial proved there is no benefit of adjuvant IFN in OS patients [162]. Systemic treatment use of IL-2 has limited effects in survival due to life-threatening side effects [163]. Aerosol IL-2 has been demonstrated to target metastatic lung disease by recruiting NK cells to the lungs $[164,165]$.
A clinical trial using aerosol IL-2 in metastatic lung lesions is underway (Table 1).

\subsubsection{Other Immunotherapies}

Other immunotherapy approaches currently being investigated in clinical trials include tumor vaccines using tumor antigens or autologous antigen-presenting cells loaded with tumor antigens, T-cell and NK-cell adoptive therapy, and targeted therapy using antibodies for tumor antigens (GD2) or to enhance T-cell activation (ipilimumab) (Table 1). Immunotherapy approaches provide exciting new avenues for pediatric sarcoma treatment.

\subsection{Environmental Interactions: Matrix and Vasculature}

Part of the pathogenesis of bone sarcomas includes the ability to invade through extracellular matrix tissues and to recruit a new blood supply as tumors grow [166]. As a part of hematogenous metastasis, tumor cells must also gain access to the endovascular space [91]. These activities typically proceed through hijacking normal biological processes that are then exploited by tumor cells to facilitate their growth and spread [167].

\subsubsection{Matric Metalloproteases}

Matrix metalloproteases (MMPs) are important mediators of invasion and metastatic disease. Expression of MMPs allows tumor cells to effectively degrade extracellular matrix, which in turn allows tumor growth and supplements cancer cells with growth factors [168]. Enhanced expression of MMPs is found in tumors, including pediatric sarcomas [169]. Inhibition of MMP2 and MMP9 affects OS and ES tumor growth and metastasis formation [7, 111, 169, 170]. MMPs inhibition has also been observed in animal models using bisphosphonates [128, 168].

\subsubsection{Vascular Endothelial Growth Factor Receptor}

VEGF ligands and receptors, as crucial regulators of tumor-associated angiogenesis and vasculogenesis, have been observed to be overexpressed in OS and ES [27, 171], relative to corresponding normal tissues. High levels of VEGF were predictive of pulmonary metastasis and poor prognosis for both diseases in several studies [172-174]. Preclinical efficacy of VEGF-based therapeutics, including anti-VEGF antibodies and small-molecule inhibitors against VEGFR, has been confirmed in pediatric bone sarcomas [27, 175]. The anti-VEGF mAb bevacizumab demonstrated some clinical benefit as monotherapy or in combination with doxorubicin in patients with recurrent ES 
$[176,177]$. Three phase II trials of bevacizumab in combination with chemotherapy for patients with OS and ES are currently underway. Further, several multi-kinase inhibitors that target VEGFR, including sunitinib, sorafenib, pazopanib, dasatinib, and cediranib, have demonstrated growth inhibition in OS models in preclinical studies [21]. Clinical trials of several of these compounds in bone sarcomas are in progress (Table 1).

\section{Discussion}

Treatment of pediatric bone sarcomas is complex, requiring multimodal therapy and a comprehensive approach, best delivered in a medical center experienced in caring for children with OS and ES. The field has certainly advanced since chemotherapy became widely accepted in the treatment of these diseases in the 1970s and 1980s, but our inability to improve outcomes in the past 20 or more years underscores the importance of finding new approaches.

It is now clear that cancer therapy, rather than focusing on delivering toxins at maximally tolerated doses, needs to exploit the expanding understanding of tumor biology, both for the signaling within the cells themselves and the interactions between cancer cells and their environment. At the same time, the enthusiasm for novel therapies needs to be tempered by the reality of assessing primarily those agents that are likely to be brought forward for regulatory approval. In this way, as a field, we can avoid the kinds of disappointment that arose from the IGF-1R antibody therapies, which 'died on the vine' not because of a lack of efficacy in bone sarcoma, but because these agents did not have an identified utility for a common adult malignancy and were, therefore, financially non-viable for further development. Even more important, good clinical trial design needs to be supported by excellent preclinical evidence [178] so we can avoid rushing into large, expensive clinical trials in children that result in no improvement in outcome and expose children to unnecessary toxicity [58]. However, what should not impede progress is a misguided effort to 'protect children from the risk' of testing targeted therapies when there is sound basis for the evaluation. For the most part, children tolerate all therapies better than do adults, presumably because they have less 'wear and tear' and are generally more resilient than adults. Even the known childspecific concerns, such as the reduced growth that is known to result from samarium therapy [179] or that may be a concern for hedgehog inhibitors [105], needs to be balanced against the potential benefit to a patient with a poor prognosis. As one parent of a 10-year-old girl with advanced OS seen in our institution articulated, "I would rather have her alive and short than not have her at all".
The investigations most urgently needed now are what treatments to apply during a minimal disease state for patients at high risk of relapse before overt treatment-resistant metastases are identified. An ideal therapy would be relatively non-toxic, allowing its use for a prolonged period after cytotoxic therapy is complete, and would specifically attack the signaling pathways that allow for prolonged survival of treatment-resistant dormant tumor cells. Large genomic studies and personalized therapy may help us to identify those patients at greatest risk of recurrence, but these approaches may not give insight into the biology of dormancy, nor of putative cancer stem cells. The focus of the field now needs to turn to understanding how OS and ES persist in these patients, and which approaches would best eradicate the remaining tumor cells at that stage.

Acknowledgments Ms. Rivera-Valentin and Dr. Zhu have no conflicts of interest that are directly relevant to this manuscript. Dr. Hughes does serve as the principle investigator of a phase I, first-inchildren trial of panitumumab and receives salary support for this effort. Ms. Rivera-Valentin is supported by Diversity Supplement R01CA149501-03S1 from the National Cancer Institute. Drs. Hughes and Zhu were supported by R01CA141208, and Dr. Hughes is also supported by 1R01CA149501.

Open Access This article is distributed under the terms of the Creative Commons Attribution-NonCommercial 4.0 International License (http://creativecommons.org/licenses/by-nc/4.0/), which permits any noncommercial use, distribution, and reproduction in any medium, provided you give appropriate credit to the original author(s) and the source, provide a link to the Creative Commons license, and indicate if changes were made.

\section{References}

1. Cheng YY, Huang L, Lee KM, Li K, Kumta SM. Alendronate regulates cell invasion and MMP-2 secretion in human osteosarcoma cell lines. Pediatr Blood Cancer. 2004;42(5):410-5 (Epub 2004/03/30).

2. Luetke A, Meyers PA, Lewis I, Juergens H. Osteosarcoma treatment-where do we stand? A state of the art review. Cancer Treat Rev. 2014;40(4):523-32.

3. Janeway KA, Grier HE. Sequelae of osteosarcoma medical therapy: a review of rare acute toxicities and late effects. Lancet Oncol. 2010;11(7):670-8.

4. Sybil Biermann J, Adkins DR, Agulnik M, Benjamin RS, Brigman B, Butrynski JE, et al. Bone cancer: clinical practice guidelines in oncology. JNCCN. 2013;11(6):688-723.

5. Whelan J, Seddon B, Perisoglu M. Management of osteosarcoma. Curr Treat Options Oncol. 2006;7(6):444-55.

6. Longhi A, Errani C, De Paolis M, Mercuri M, Bacci G. Primary bone osteosarcoma in the pediatric age: state of the art. Cancer Treat Rev. 2006;32(6):423-36 (Epub 2006/07/25).

7. Cho HJ, Lee TS, Park JB, Park KK, Choe JY, Sin DI, et al. Disulfiram suppresses invasive ability of osteosarcoma cells via the inhibition of MMP-2 and MMP-9 expression. J Biochem Mol Biol. 2007;40(6):1069-76 (Epub 2007/12/01)

8. Leow PC, Tian Q, Ong ZY, Yang Z, Ee PL. Antitumor activity of natural compounds, curcumin and PKF118-310, as Wnt/beta- 
catenin antagonists against human osteosarcoma cells. Invest New Drugs. 2010;28(6):766-82 (Epub 2009/09/05).

9. Hughes DP. How the NOTCH pathway contributes to the ability of osteosarcoma cells to metastasize. Cancer Treat Res. 2009;152:479-96 (Epub 2010/03/10).

10. Ando K, Mori K, Verrecchia F, Marc B, Redini F, Heymann D. Molecular alterations associated with osteosarcoma development. Sarcoma. 2012;2012:523432 (Epub 2012/03/27).

11. Eccles SA, Welch DR. Metastasis: recent discoveries and novel treatment strategies. Lancet. 2007;369(9574):1742-57 (Epub 2007/05/22)

12. Steeg PS. Tumor metastasis: mechanistic insights and clinical challenges. Nat Med. 2006;12(8):895-904 (Epub 2006/08/08).

13. Laverdiere C, Hoang BH, Yang R, Sowers R, Qin J, Meyers PA, et al. Messenger RNA expression levels of CXCR4 correlate with metastatic behavior and outcome in patients with osteosarcoma. Clin Cancer Res. 2005;11(7):2561-7 (Epub 2005/04/09)

14. Huang CY, Lee CY, Chen MY, Yang WH, Chen YH, Chang $\mathrm{CH}$, et al. Stromal cell-derived factor-1/CXCR4 enhanced motility of human osteosarcoma cells involves MEK1/2, ERK and NF-kappaB-dependent pathways. J Cell Physiol. 2009;221(1):204-12 (Epub 2009/06/06).

15. Pradelli E, Karimdjee-Soilihi B, Michiels JF, Ricci JE, Millet MA, Vandenbos F, et al. Antagonism of chemokine receptor CXCR3 inhibits osteosarcoma metastasis to lungs. Int J Cancer. 2009;125(11):2586-94 (Epub 2009/06/23).

16. Biermann JS, Adkins DR, Agulnik M, Benjamin RS, Brigman B, Butrynski JE, et al. Bone cancer. J Natl Compr Canc Netw. 2013;11(6):688-723.

17. Grier HE, Krailo MD, Tarbell NJ, Link MP, Fryer CJH, Pritchard DJ, et al. Addition of ifosfamide and etoposide to standard chemotherapy for Ewing's sarcoma and primitive neuroectodermal tumor of bone. N Engl J Med. 2003;348(8):694-701.

18. Kim SY, Lee CH, Midura BV, Yeung C, Mendoza A, Hong SH, et al. Inhibition of the CXCR4/CXCL12 chemokine pathway reduces the development of murine pulmonary metastases. Clin Exp Metastasis. 2008;25(3):201-11 (Epub 2007/12/12).

19. Meyers PA, Schwartz CL, Krailo MD, Healey JH, Bernstein ML, Betcher D, et al. Osteosarcoma: the addition of muramyl tripeptide to chemotherapy improves overall survival - a report from the Children's Oncology Group. J Clin Oncol. 2008;26(4):633-8.

20. Zwick E, Bange J, Ullrich A. Receptor tyrosine kinase signalling as a target for cancer intervention strategies. Endocr Relat Cancer. 2001;8(3):161-73 (Epub 2001/09/22).

21. Gill J, Ahluwalia MK, Geller D, Gorlick R. New targets and approaches in osteosarcoma. Pharmacol Ther. 2013;137(1):89-99 (Epub 2012/09/18).

22. Jully B, Rajkumar T. Potential molecular targets for Ewing's sarcoma therapy. Indian $\mathrm{J}$ Med Paediatr Oncol. 2012;33(4): 195-202 (Epub 2013/04/13).

23. Arcaro A. Targeting the insulin-like growth factor-1 receptor in human cancer. Front Pharmacol. 2013;4:30 (Epub 2013/03/26).

24. Pollak M. Insulin and insulin-like growth factor signalling in neoplasia. Nat Rev Cancer. 2008;8(12):915-28 (Epub 2008/11/ 26).

25. van Valen F, Winkelmann W, Jurgens H. Type I and type II insulin-like growth factor receptors and their function in human Ewing's sarcoma cells. J Cancer Res Clin Oncol. 1992;118(4):269-75 (Epub 1992/01/01).

26. Scotlandi K, Benini S, Sarti M, Serra M, Lollini PL, Maurici D, et al. Insulin-like growth factor I receptor-mediated circuit in Ewing's sarcoma/peripheral neuroectodermal tumor: a possible therapeutic target. Cancer Res. 1996;56(20):4570-4 (Epub 1996/10/15)
27. Hassan SE, Bekarev M, Kim MY, Lin J, Piperdi S, Gorlick R, et al. Cell surface receptor expression patterns in osteosarcoma. Cancer. 2012;118(3):740-9 (Epub 2011/07/14).

28. Wang YH, Han XD, Qiu Y, Xiong J, Yu Y, Wang B, et al. Increased expression of insulin-like growth factor-1 receptor is correlated with tumor metastasis and prognosis in patients with osteosarcoma. J Surg Oncol. 2012;105(3):235-43 (Epub 2011/08/26).

29. Martin Liberal J, Lagares-Tena L, Sainz-Jaspeado M, MateoLozano S, Garcia Del Muro X, Tirado OM. Targeted therapies in sarcomas: challenging the challenge. Sarcoma. 2012;2012:626094 (Epub 2012/06/16).

30. Pappo AS, Vassal G, Crowley JJ, Bolejack V, Hogendoorn PC, Chugh R, et al. A phase 2 trial of R1507, a monoclonal antibody to the insulin-like growth factor-1 receptor (IGF-1R), in patients with recurrent or refractory rhabdomyosarcoma, osteosarcoma, synovial sarcoma, and other soft tissue sarcomas: results of a Sarcoma Alliance for Research Through Collaboration study. Cancer. 2014;120(16):2448-56.

31. Juergens H, Daw NC, Geoerger B, Ferrari S, Villarroel M, Aerts I, et al. Preliminary efficacy of the anti-insulin-like growth factor type 1 receptor antibody figitumumab in patients with refractory Ewing sarcoma. J Clin Oncol. 2011;29(34):4534-40 (Epub 2011/10/26).

32. Schoffski P, Adkins D, Blay JY, Gil T, Elias AD, Rutkowski P, et al. An open-label, phase 2 study evaluating the efficacy and safety of the anti-IGF-1R antibody cixutumumab in patients with previously treated advanced or metastatic soft-tissue sarcoma or Ewing family of tumours. Eur $\mathrm{J}$ Cancer. 2013;49(15):3219-28 (Epub 2013/07/10).

33. Malempati S, Weigel B, Ingle AM, Ahern $\mathrm{CH}$, Carroll JM, Roberts CT, et al. Phase I/II trial and pharmacokinetic study of cixutumumab in pediatric patients with refractory solid tumors and Ewing sarcoma: a report from the Children's Oncology Group. J Clin Oncol. 2012;30(3):256-62 (Epub 2011/12/21).

34. von Mehren M, Britten CD, Pieslor P, Saville W, Vassos A, Harris S, et al. A phase 1, open-label, dose-escalation study of BIIB022 (anti-IGF-1R monoclonal antibody) in subjects with relapsed or refractory solid tumors. Invest New Drugs. 2014;32(3):518-25 (Epub 2014/01/25).

35. Soria JC, Massard C, Lazar V, Ozoux ML, Mery-Mignard D, Deslandes A, et al. A dose finding, safety and pharmacokinetic study of AVE1642, an anti-insulin-like growth factor-1 receptor (IGF-1R/CD221) monoclonal antibody, administered as a single agent and in combination with docetaxel in patients with advanced solid tumours. Eur J Cancer. 2013;49(8):1799-807 (Epub 2013/03/15).

36. Tap WD, Demetri G, Barnette P, Desai J, Kavan P, Tozer R, et al. Phase II study of ganitumab, a fully human anti-type-1 insulin-like growth factor receptor antibody, in patients with metastatic Ewing family tumors or desmoplastic small round cell tumors. J Clin Oncol. 2012;30(15):1849-56 (Epub 2012/04/ 18).

37. Atzori F, Tabernero J, Cervantes A, Prudkin L, Andreu J, Rodriguez-Braun E, et al. A phase I pharmacokinetic and pharmacodynamic study of dalotuzumab (MK-0646), an anti-insulinlike growth factor-1 receptor monoclonal antibody, in patients with advanced solid tumors. Clin Cancer Res. 2011;17(19):6304-12 (Epub 2011/08/04).

38. Friedbichler K, Hofmann MH, Kroez M, Ostermann E, Lamche HR, Koessl C, et al. Pharmacodynamic and antineoplastic activity of BI 836845, a fully human IGF ligand-neutralizing antibody, and mechanistic rationale for combination with rapamycin. Mol Cancer Ther. 2014;13(2):399-409 (Epub 2013/12/04).

39. Gao J, Chesebrough JW, Cartlidge SA, Ricketts SA, Incognito L, Veldman-Jones M, et al. Dual IGF-I/II-neutralizing antibody 
MEDI-573 potently inhibits IGF signaling and tumor growth. Cancer Res. 2011;71(3):1029-40 (Epub 2011/01/20).

40. Haluska P, Menefee ME, Plimack ER, Rosenberg JE, Northfelt DW, LaVallee T, et al. Phase I dose escalation study of MEDI573, a bispecific, anti-ligand monoclonal antibody against IGF-I and IGF-II, in patients with advanced solid tumors. Clin Cancer Res. 2014;20(18):4747-57.

41. Feng Y, Dimitrov DS. Antibody-based therapeutics against components of the IGF system. Oncoimmunology. 2012;1(8):1390-1 (Epub 2012/12/18).

42. Gualberto A, Pollak M. Emerging role of insulin-like growth factor receptor inhibitors in oncology: early clinical trial results and future directions. Oncogene. 2009;28(34):3009-21 (Epub 2009/07/08).

43. Akatsuka T, Wada T, Kokai Y, Sawada N, Yamawaki S, Ishii S. Loss of ErbB2 expression in pulmonary metastatic lesions in osteosarcoma. Oncology. 2001;60(4):361-6.

44. Maitra A, Wanzer D, Weinberg AG, Ashfaq R. Amplification of the HER-2/neu oncogene is uncommon in pediatric osteosarcomas. Cancer. 2001;92(3):677-83.

45. Kilpatrick SE, Geisinger KR, King TS, Sciarrotta J, Ward WG, Gold SH, et al. Clinicopathologic analysis of HER-2/neu immunoexpression among various histologic subtypes and grades of osteosarcoma. Mod Pathol. 2001;14(12):1277-83.

46. Thomas DG, Giordano TJ, Sanders D, Biermann JS, Baker L. Absence of HER2/neu gene expression in osteosarcoma and skeletal Ewing's sarcoma. Clin Cancer Res. 2002;8(3):788-93.

47. Akatsuka T, Wada T, Kokai Y, Kawaguchi S, Isu K, Yamashiro $\mathrm{K}$, et al. ErbB2 expression is correlated with increased survival of patients with osteosarcoma. Cancer. 2002;94(5):1397-404.

48. Gorlick S, Barkauskas DA, Krailo M, Piperdi S, Sowers R, Gill $\mathrm{J}$, et al. HER-2 expression is not prognostic in osteosarcoma; a Children's Oncology Group prospective biology study. Pediatr Blood Cancer. 2014;61(9):1558-64 (Epub 2014/04/23).

49. Onda M, Matsuda S, Higaki S, Iijima T, Fukushima J, Yokokura A, et al. ErbB-2 expression is correlated with poor prognosis for patients with osteosarcoma. Cancer. 1996;77(1):71-8.

50. Zhou H, Randall R, Brothman A, Maxwell T, Coffin C, Goldsby $\mathrm{R}$. Her-2/neu expression in osteosarcoma increases risk of lung metastasis and can be associated with gene amplification. J Pediatr Hematol Oncol. 2003;25(1):27-32.

51. Gorlick R, Huvos AG, Heller G, Aledo A, Beardsley GP, Healey $\mathrm{JH}$, et al. Expression of HER2/erbB-2 correlates with survival in osteosarcoma. J Clin Oncol. 1999;17(9):2781-8.

52. Fellenberg J, Krauthoff A, Pollandt K, Delling G, Parsch D. Evaluation of the predictive value of Her-2/neu gene expression on osteosarcoma therapy in laser-microdissected paraffin-embedded tissue. Lab Invest. 2004;84(1):113-21.

53. Ferrari S, Bertoni F, Zanella L, Setola E, Bacchini P, Alberghini $\mathrm{M}$, et al. Evaluation of P-glycoprotein, HER-2/ErbB-2, p53, and Bcl-2 in primary tumor and metachronous lung metastases in patients with high-grade osteosarcoma. Cancer. 2004;100(9):1936-42.

54. McAllister SS, Weinberg RA. Tumor-host interactions: a farreaching relationship. J Clin Oncol. 2010;28(26):4022-8.

55. Li YG, Geng X. A meta-analysis on the association of HER-2 overexpression with prognosis in human osteosarcoma. Eur $\mathbf{J}$ Cancer Care. 2010;19(3):313-6 (Epub 2009/08/28).

56. Fergenbaum JH, Garcia-Closas M, Hewitt SM, Lissowska J, Sakoda LC, Sherman ME. Loss of antigenicity in stored sections of breast cancer tissue microarrays. Cancer Epidemiol Biomark Prev. 2004;13(4):667-72.

57. Xie R, Chung J-Y, Ylaya K, Williams RL, Guerrero N, Nakatsuka $\mathrm{N}$, et al. Factors influencing the degradation of archival formalin-fixed paraffin-embedded tissue sections. J Histochem Cytochem. 2011;59(4):356-65.
58. Ebb D, Meyers P, Grier H, Bernstein M, Gorlick R, Lipshultz SE, et al. Phase II trial of trastuzumab in combination with cytotoxic chemotherapy for treatment of metastatic osteosarcoma with human epidermal growth factor receptor 2 overexpression: a report from the children's oncology group. J Clin Oncol. 2012;30(20):2545-51 (Epub 2012/06/06).

59. Roy V, Perez EA. Beyond trastuzumab: small molecule tyrosine kinase inhibitors in HER-2-positive breast cancer. Oncologist. 2009; 14(11):1061-9 (Epub 2009/11/06).

60. Hua Y, Gorshkov K, Yang Y, Wang W, Zhang N, Hughes DP. Slow down to stay alive: HER4 protects against cellular stress and confers chemoresistance in neuroblastoma. Cancer. 2012;118(20):5140-54 (Epub 2012/03/15).

61. Hua Y, Yang Y, Hughes D. Abstract 197: multi-cellular tumor spheroids in vitro model reveals a critical role of ERBB4 in survival of osteosarcoma. Cancer Res. 2011;71(8 Suppl):197.

62. Kang H-G, Jenabi JM, Zhang J, Keshelava N, Shimada H, May WA, et al. E-cadherin cell-cell adhesion in ewing tumor cells mediates suppression of anoikis through activation of the ErbB4 tyrosine kinase. Cancer Res. 2007;67(7):3094-105.

63. Hughes DP, Thomas DG, Giordano TJ, Baker LH, McDonagh KT. Cell surface expression of epidermal growth factor receptor and Her-2 with nuclear expression of Her-4 in primary osteosarcoma. Cancer Res. 2004;64(6):2047-53 (Epub 2004/03/18).

64. Mendoza-Naranjo A, El-Naggar A, Wai DH, Mistry P, Lazic N, Ayala FR, et al. ERBB4 confers metastatic capacity in Ewing sarcoma. EMBO Mol Med. 2013;5(7):1019-34 (Epub 2013/05/ 18).

65. Fredriksson L, Li H, Eriksson U. The PDGF family: four gene products form five dimeric isoforms. Cytokine Growth Factor Rev. 2004;15(4):197-204 (Epub 2004/06/23).

66. Wang YX, Mandal D, Wang S, Hughes D, Pollock RE, Lev D, et al. Inhibiting platelet-derived growth factor beta reduces Ewing's sarcoma growth and metastasis in a novel orthotopic human xenograft model. Vivo. 2009;23(6):903-9 (Epub 2009/12/22).

67. Uren A, Merchant MS, Sun CJ, Vitolo MI, Sun Y, Tsokos M, et al. Beta-platelet-derived growth factor receptor mediates motility and growth of Ewing's sarcoma cells. Oncogene. 2003;22(15):2334-42 (Epub 2003/04/18).

68. Sulzbacher I, Traxler M, Mosberger I, Lang S, Chott A. Plateletderived growth factor-AA and -alpha receptor expression suggests an autocrine and/or paracrine loop in osteosarcoma. Mod Pathol. 2000;13(6):632-7 (Epub 2000/06/30).

69. Kubo T, Piperdi S, Rosenblum J, Antonescu CR, Chen W, Kim HS, et al. Platelet-derived growth factor receptor as a prognostic marker and a therapeutic target for imatinib mesylate therapy in osteosarcoma. Cancer. 2008;112(10):2119-29.

70. Bond M, Bernstein ML, Pappo A, Schultz KR, Krailo M, Blaney $\mathrm{SM}$, et al. A phase II study of imatinib mesylate in children with refractory or relapsed solid tumors: a Children's Oncology Group study. Pediatr Blood Cancer. 2008;50(2):254-8 (Epub 2007/01/31).

71. Chao J, Budd GT, Chu P, Frankel P, Garcia D, Junqueira M, et al. Phase II clinical trial of imatinib mesylate in therapy of KIT and/or PDGFRalpha-expressing Ewing sarcoma family of tumors and desmoplastic small round cell tumors. Anticancer Res. 2010;30(2):547-52 (Epub 2010/03/25).

72. Yu Y, Khan J, Khanna C, Helman L, Meltzer PS, Merlino G. Expression profiling identifies the cytoskeletal organizer ezrin and the developmental homeoprotein Six-1 as key metastatic regulators. Nat Med. 2004;10(2):175-81.

73. Khanna C, Wan X, Bose S, Cassaday R, Olomu O, Mendoza A, et al. The membrane-cytoskeleton linker ezrin is necessary for osteosarcoma metastasis. Nat Med. 2004;10(2):182-6 (Epub 2004/01/06). 
74. Ren L, Khanna C. Role of ezrin in osteosarcoma metastasis. Adv Exp Med Biol. 2014;804:181-201.

75. Krishnan K, Bruce B, Hewitt S, Thomas D, Khanna C, Helman LJ. Ezrin mediates growth and survival in Ewing's sarcoma through the AKT/mTOR, but not the MAPK, signaling pathway. Clin Exp Metastasis. 2006;23(3-4):227-36.

76. Bulut G, Hong SH, Chen K, Beauchamp EM, Rahim S, Kosturko $\mathrm{GW}$, et al. Small molecule inhibitors of ezrin inhibit the invasive phenotype of osteosarcoma cells. Oncogene. 2012;31(3):269-81.

77. Kim SY, Helman LJ. Strategies to explore new approaches in the investigation and treatment of osteosarcoma. Cancer Treat Res. 2009;152:517-28.

78. Bagatell R, Norris R, Ingle AM, Ahern C, Voss S, Fox E, et al. Phase 1 trial of temsirolimus in combination with irinotecan and temozolomide in children, adolescents and young adults with relapsed or refractory solid tumors: a Children's Oncology Group Study. Pediatr Blood Cancer. 2014;61(5):833-9.

79. Gobin B, Battaglia S, Lanel R, Chesneau J, Amiaud J, Redini F, et al. NVP-BEZ235, a dual PI3K/mTOR inhibitor, inhibits osteosarcoma cell proliferation and tumor development in vivo with an improved survival rate. Cancer Lett. 2014;344(2):291-8.

80. Martin-Liberal J, Gil-Martin M, Sainz-Jaspeado M, Gonzalo N, Rigo R, Colom H, et al. Phase I study and preclinical efficacy evaluation of the mTOR inhibitor sirolimus plus gemcitabine in patients with advanced solid tumours. $\mathrm{Br} \mathrm{J}$ Cancer. 2014;111(5):858-65.

81. Mita MM, Gong J, Chawla SP. Ridaforolimus in advanced or metastatic soft tissue and bone sarcomas. Expert Rev Clin Pharmacol. 2013;6(5):465-82.

82. Gore L, Trippett TM, Katzenstein HM, Boklan J, Narendran A, Smith A, et al. A multicenter, first-in-pediatrics, phase 1, pharmacokinetic and pharmacodynamic study of ridaforolimus in patients with refractory solid tumors. Clin Cancer Res. 2013;19(13):3649-58.

83. Mahajan A, Woo SY, Kornguth DG, Hughes D, Huh W, Chang EL, et al. Multimodality treatment of osteosarcoma: radiation in a high-risk cohort. Pediatr Blood Cancer. 2008;50(5):976-82.

84. Demetri GD, Chawla SP, Ray-Coquard I, Le Cesne A, Staddon AP, Milhem MM, et al. Results of an international randomized phase III trial of the mammalian target of rapamycin inhibitor ridaforolimus versus placebo to control metastatic sarcomas in patients after benefit from prior chemotherapy. J Clin Oncol. 2013;31(19):2485-92.

85. Hingorani P, Zhang W, Gorlick R, Kolb EA. Inhibition of Src phosphorylation alters metastatic potential of osteosarcoma in vitro but not in vivo. Clin Cancer Res. 2009;15(10):3416-22.

86. Shor AC, Keschman EA, Lee FY, Muro-Cacho C, Letson GD, Trent JC, et al. Dasatinib inhibits migration and invasion in diverse human sarcoma cell lines and induces apoptosis in bone sarcoma cells dependent on SRC kinase for survival. Cancer Res. 2007;67(6):2800-8.

87. Timeus F, Crescenzio N, Fandi A, Doria A, Foglia L, Cordero di Montezemolo L. In vitro antiproliferative and antimigratory activity of dasatinib in neuroblastoma and Ewing sarcoma cell lines. Oncol Rep. 2008;19(2):353-9.

88. Ott U, Odermatt E, Engel J, Furthmayr H, Timpl R. Protease resistance and conformation of laminin. Eur $\mathrm{J}$ Biochem. 1982;123(1):63-72.

89. Takahashi S, Miyazaki M, Okamoto I, Ito Y, Ueda K, Seriu T, et al. Phase I study of dasatinib (BMS-354825) in Japanese patients with solid tumors. Cancer Sci. 2011;102(11):2058-64.

90. Paridaen JT, Huttner WB. Neurogenesis during development of the vertebrate central nervous system. EMBO Rep. 2014;15(4):351-64.

91. McManus MM, Weiss KR, Hughes DPM. Understanding the role of notch in osteosarcoma. In: Kleinerman ES, editor.
Current advances in osteosarcoma. New York: Springer Science and Business Media; 2014.

92. Stewart KS, Zhou Z, Zweidler-McKay P, Kleinerman ES. Deltalike ligand 4-Notch signaling regulates bone marrow-derived pericyte/vascular smooth muscle cell formation. Blood. 2011;117(2):719-26.

93. Engin F, Bertin T, Ma O, Jiang MM, Wang L, Sutton RE, et al. Notch signaling contributes to the pathogenesis of human osteosarcomas. Hum Mol Genet. 2009;18(8):1464-70.

94. Hughes DPM. How the NOTCH pathway contributes to the ability of osteosarcoma cells to metastasize. In: Jaffe N, Bruland OS, Bielack S, editors. Pediatric and adolescent osteosarcoma. 152nd ed. New York: Springer; 2009. p. 479-96.

95. Mu X, Isaac C, Greco N, Huard J, Weiss K. Notch signaling is associated with ALDH activity and an aggressive metastatic phenotype in murine osteosarcoma cells. Front Oncol. 2013;3.

96. McManus MM, Weiss KR, Hughes DP. Understanding the role of notch in osteosarcoma. Adv Exp Med Biol. 2014;804:67-92.

97. Tolcher AW, Messersmith WA, Mikulski SM, Papadopoulos KP, Kwak EL, Gibbon DG, et al. Phase I study of RO4929097, a gamma secretase inhibitor of Notch signaling, in patients with refractory metastatic or locally advanced solid tumors. J Clin Oncol. 2012;30(19):2348-53.

98. Hughes DPM, Kummar S, Lazar AJ. New, tolerable \{gamma\}secretase inhibitor takes desmoid down a notch. Clin Cancer Res. 2015;21(1):7-9.

99. Lo WW, Pinnaduwage D, Gokgoz N, Wunder JS, Andrulis IL. Aberrant hedgehog signaling and clinical outcome in osteosarcoma. Sarcoma. 2014;2014:261804.

100. Lo WW, Wunder JS, Dickson BC, Campbell V, McGovern K, Alman BA, et al. Involvement and targeted intervention of dysregulated Hedgehog signaling in osteosarcoma. Cancer. 2014;120(4):537-47.

101. Kelleher FC, Cain JE, Healy JM, Watkins DN, Thomas DM. Prevailing importance of the hedgehog signaling pathway and the potential for treatment advancement in sarcoma. Pharmacol Ther. 2012;136(2):153-68.

102. Joo J, Christensen L, Warner K, States L, Kang HG, Vo K, et al. GLI1 is a central mediator of EWS/FLI1 signaling in Ewing tumors. PLoS One. 2009;4(10):e7608.

103. Beauchamp EM, Ringer L, Bulut G, Sajwan KP, Hall MD, Lee $\mathrm{YC}$, et al. Arsenic trioxide inhibits human cancer cell growth and tumor development in mice by blocking Hedgehog/GLI pathway. J Clin Investig. 2011;121(1):148-60.

104. Wagner AJ, Messersmith WA, Shaik MN, Li S, Zheng X, McLachlan KR, et al. A phase I study of PF-04449913, an oral hedgehog inhibitor, in patients with advanced solid tumors. Clin Cancer Res. 2015;21(5):1044-51.

105. Kimura H, Ng JMY, Curran T. Transient inhibition of the hedgehog pathway in young mice causes permanent defects in bone structure. Cancer Cell. 2008;13(3):249-60.

106. Fouladi M, Furman WL, Chin T, Freeman BB 3rd, Dudkin L, Stewart CF, et al. Phase I study of depsipeptide in pediatric patients with refractory solid tumors: a Children's Oncology Group report. J Clin Oncol. 2006;24(22):3678-85.

107. Zorzi AP, Bernstein M, Samson Y, Wall DA, Desai S, Nicksy D, et al. A phase I study of histone deacetylase inhibitor, pracinostat (SB939), in pediatric patients with refractory solid tumors: IND203 a trial of the NCIC IND program/C17 pediatric phase I consortium. Pediatr Blood Cancer. 2013;60(11):1868-74.

108. Berghuis D, Schilham MW, Vos HI, Santos SJ, Kloess S, Buddingh EP, et al. Histone deacetylase inhibitors enhance expression of NKG2D ligands in Ewing sarcoma and sensitize for natural killer cell-mediated cytolysis. Clin Sarcoma Res. 2012;2(1):8.

109. Zhu S, Denman CJ, Cobanoglu ZS, Kiany S, Lau CC, Gottschalk SM, et al. The narrow-spectrum HDAC inhibitor 
entinostat enhances NKG2D expression without NK cell toxicity, leading to enhanced recognition of cancer cells. Pharm Res. 2015;32(3):779-92.

110. Geryk-Hall M, Yang Y, Hughes DP. Driven to death: inhibition of farnesylation increases Ras activity in osteosarcoma and promotes growth arrest and cell death. Mol Cancer Ther. 2010;9(5):1111-9.

111. Tsubaki M, Satou T, Itoh T, Imano M, Ogaki M, Yanae M, et al. Reduction of metastasis, cell invasion, and adhesion in mouse osteosarcoma by YM529/ONO-5920-induced blockade of the Ras/MEK/ERK and Ras/PI3K/Akt pathway. Toxicol Appl Pharmacol. 2012;259(3):402-10.

112. Tsubaki M, Yamazoe Y, Yanae M, Satou T, Itoh T, Kaneko J, et al. Blockade of the Ras/MEK/ERK and Ras/PI3 K/Akt pathways by statins reduces the expression of bFGF, HGF, and TGF-beta as angiogenic factors in mouse osteosarcoma. Cytokine. 2011;54(1):100-7.

113. Gharanei S, Brini AT, Vaiyapuri S, Alholle A, Dallol A, Arrigoni E, et al. RASSF2 methylation is a strong prognostic marker in younger age patients with Ewing sarcoma. Epigenetics. 2013;8(9):893-8.

114. Hingorani P, Zhang W, Lin J, Liu L, Guha C, Kolb EA. Systemic administration of reovirus (Reolysin) inhibits growth of human sarcoma xenografts. Cancer. 2011;117(8):1764-74.

115. Mita AC, Sankhala K, Sarantopoulos J, Carmona J, Okuno S, Goel S, et al. A phase II study of intravenous (IV) wild-type reovirus (Reolysin) in the treatment of patients with bone and soft tissue sarcomas metastatic to the lung. ASCO Meeting Abstracts. 2009;27(15S):10524.

116. Pishas KI, Al-Ejeh F, Zinonos I, Kumar R, Evdokiou A, Brown MP, et al. Nutlin-3a is a potential therapeutic for ewing sarcoma. Clin Cancer Res. 2011;17(3):494-504.

117. Sonnemann J, Palani CD, Wittig S, Becker S, Eichhorn F, Voigt A, et al. Anticancer effects of the p53 activator nutlin-3 in Ewing's sarcoma cells. Eur J Cancer. 2011;47(9):1432-41.

118. Wang B, Fang L, Zhao H, Xiang T, Wang D. MDM2 inhibitor Nutlin-3a suppresses proliferation and promotes apoptosis in osteosarcoma cells. Acta Biochim Biophys Sin. 2012;44(8):685-91.

119. Carol H, Reynolds CP, Kang MH, Keir ST, Maris JM, Gorlick $\mathrm{R}$, et al. Initial testing of the MDM2 inhibitor RG7112 by the Pediatric Preclinical Testing Program. Pediatr Blood Cancer. 2013;60(4):633-41.

120. Balkwill FR, Capasso M, Hagemann T. The tumor microenvironment at a glance. J Cell Sci. 2012;125(23):5591-6.

121. Fang H, DeClerck YA. Targeting the tumor microenvironment: from understanding pathways to effective clinical trials. Cancer Res. 2013;73(16):4965-77.

122. Miles FL, Sikes RA. Insidious changes in stromal matrix fuel cancer progression. Mol Cancer Res. 2014;12(3):297-312.

123. Paez D, Labonte MJ, Bohanes P, Zhang W, Benhanim L, Ning $\mathrm{Y}$, et al. Cancer dormancy: a model of early dissemination and late cancer recurrence. Clin Cancer Res. 2012;18(3):645-53.

124. Sato M, Grasser W, Endo N, Akins R, Simmons H, Thompson $\mathrm{DD}$, et al. Bisphosphonate action. Alendronate localization in rat bone and effects on osteoclast ultrastructure. J Clin Investig. 1991;88(6):2095-105 (Epub 1991/12/01).

125. Diel IJ, Solomayer EF, Bastert G. Bisphosphonates and the prevention of metastasis: first evidences from preclinical and clinical studies. Cancer. 2000;88(12 Suppl):3080-8 (Epub 2000/07/18).

126. Zhou Z, Guan H, Duan X, Kleinerman ES. Zoledronic acid inhibits primary bone tumor growth in Ewing sarcoma. Cancer. 2005;104(8):1713-20 (Epub 2005/08/27).

127. Ory B, Heymann MF, Kamijo A, Gouin F, Heymann D, Redini F. Zoledronic acid suppresses lung metastases and prolongs overall survival of osteosarcoma-bearing mice. Cancer. 2005; 104(11):2522-9 (Epub 2005/11/05).

128. Odri G, Kim PP, Lamoureux F, Charrier C, Battaglia S, Amiaud $\mathrm{J}$, et al. Zoledronic acid inhibits pulmonary metastasis dissemination in a preclinical model of Ewing's sarcoma via inhibition of cell migration. BMC Cancer. 2014;14:169 (Epub 2014/03/13).

129. Odri GA, Dumoucel S, Picarda G, Battaglia S, Lamoureux F, Corradini N, et al. Zoledronic acid as a new adjuvant therapeutic strategy for Ewing's sarcoma patients. Cancer Res. 2010;70(19):7610-9 (Epub 2010/09/16).

130. Sonnemann J, Eckervogt V, Truckenbrod B, Boos J, Winkelmann W, van Valen F. The bisphosphonate pamidronate is a potent inhibitor of Ewing's sarcoma cell growth in vitro. Anticancer Drugs. 2003;14(9):767-71 (Epub 2003/10/11).

131. Dass CR, Choong PF. Zoledronic acid inhibits osteosarcoma growth in an orthotopic model. Mol Cancer Ther. 2007;6(12 Pt 1):3263-70 (Epub 2007/12/20).

132. Goldenberg DM, Schlom J. The coming of age of cancer radioimmunoconjugates. Immunol Today. 1993;14(1):5-7 (Epub 1993/01/01).

133. Meyers PA, Healey JH, Chou AJ, Wexler LH, Merola PR, Morris CD, et al. Addition of pamidronate to chemotherapy for the treatment of osteosarcoma. Cancer. 2011;117(8):1736-44 (Epub 2011/04/08).

134. Goldsby RE, Fan TM, Villaluna D, Wagner LM, Isakoff MS, Meyer J, et al. Feasibility and dose discovery analysis of zoledronic acid with concurrent chemotherapy in the treatment of newly diagnosed metastatic osteosarcoma: a report from the Children's Oncology Group. Eur J Cancer. 2013;49(10):2384-91 (Epub 2013/05/15).

135. Anderson P. Samarium for osteoblastic bone metastases and osteosarcoma. Expert Opin Pharmacother. 2006;7(11):1475-86 (Epub 2006/07/25).

136. Parker C, Nilsson S, Heinrich D, Helle SI, O'Sullivan JM, Fossa $\mathrm{SD}$, et al. Alpha emitter radium-223 and survival in metastatic prostate cancer. N Engl J Med. 2013;369(3):213-23 (Epub 2013/07/19).

137. Anderson PM, Wiseman GA, Erlandson L, Rodriguez V, Trotz B, Dubansky SA, et al. Gemcitabine radiosensitization after high-dose samarium for osteoblastic osteosarcoma. Clin Cancer Res. 2005;11(19 Pt 1):6895-900 (Epub 2005/10/06).

138. Boyce BF, Xing L. Functions of RANKL/RANK/OPG in bone modeling and remodeling. Arch Biochem Biophys. 2008;473(2):139-46.

139. Wada T, Nakashima T, Hiroshi N, Penninger JM. RANKLRANK signaling in osteoclastogenesis and bone disease. Trends Mol Med. 2006;12(1):17-25.

140. Lee JA, Jung JS, Kim DH, Lim JS, Kim MS, Kong C-B, et al. RANKL expression is related to treatment outcome of patients with localized, high-grade osteosarcoma. Pediatr Blood Cancer. 2011;56(5):738-43.

141. Mori K, Le Goff B, Berreur M, Riet A, Moreau A, Blanchard F, et al. Human osteosarcoma cells express functional receptor activator of nuclear factor-kappa B. J Pathol. 2007;211(5):555-62 (Epub 2007/02/27).

142. Beristain AG, Narala SR, Di Grappa MA, Khokha R. Homotypic RANK signaling differentially regulates proliferation, motility and cell survival in osteosarcoma and mammary epithelial cells. J Cell Sci. 2012;125(Pt 4):943-55 (Epub 2012/03/ 17).

143. McClung MR, Lewiecki EM, Cohen SB, Bolognese MA, Woodson GC, Moffett AH, et al. Denosumab in postmenopausal women with low bone mineral density. N Engl J Med. 2006;354(8):821-31 (Epub 2006/02/24). 
144. Body J-J, Facon T, Coleman RE, Lipton A, Geurs F, Fan M, et al. A study of the biological receptor activator of nuclear factor-kappaB ligand inhibitor, denosumab, in patients with multiple myeloma or bone metastases from breast cancer. Clin Cancer Res. 2006;12(4):1221-8.

145. Fizazi K, Carducci M, Smith M, Damião R, Brown J, Karsh L, et al. Denosumab versus zoledronic acid for treatment of bone metastases in men with castration-resistant prostate cancer: a randomised, double-blind study. Lancet. 2011;377(9768):813-22.

146. Henry DH, Costa L, Goldwasser F, Hirsh V, Hungria V, Prausova $\mathrm{J}$, et al. Randomized, double-blind study of denosumab versus zoledronic acid in the treatment of bone metastases in patients with advanced cancer (excluding breast and prostate cancer) or multiple myeloma. J Clin Oncol. 2011;29(9):1125-32.

147. Stopeck AT, Lipton A, Body J-J, Steger GG, Tonkin K, de Boer $\mathrm{RH}$, et al. Denosumab compared with zoledronic acid for the treatment of bone metastases in patients with advanced breast cancer: a randomized, double-blind study. J Clin Oncol. 2010;28(35):5132-9.

148. Thomas D, Henshaw R, Skubitz K, Chawla S, Staddon A, Blay $\mathrm{J}-\mathrm{Y}$, et al. Denosumab in patients with giant-cell tumour of bone: an open-label, phase 2 study. Lancet Oncol. 2010;11(3):275-80.

149. Langley R, Fidler I. The seed and soil hypothesis revisited-the role of tumor-stroma interactions in metastasis to different organs. Int J Cancer. 2011;128(11):2527-35.

150. Hanahan D, Weinberg R. Hallmarks of cancer: the next generation. Cell. 2011;144(5):646-74.

151. Ando K, Heymann MF, Stresing V, Mori K, Redini F, Heymann D. Current therapeutic strategies and novel approaches in osteosarcoma. Cancers. 2013;5(2):591-616.

152. Anderson PM, Tomaras M, McConnell K. Mifamurtide in osteosarcoma-a practical review. Drugs Today (Barcelona, Spain: 1998). 2010;46(5):327-37 (Epub 2010/06/03).

153. O’Day K, Gorlick R. Novel therapeutic agents for osteosarcoma. Expert Rev Anticancer Ther. 2009;9(4):511-23 (Epub 2009/04/ 21).

154. Pedrazzoli P, Secondino S, Perfetti V, Comoli P, Montagna D. Immunotherapeutic intervention against sarcomas. J Cancer. 2011;2:350-6.

155. Shi Y, Liu CH, Roberts AI, Das J, Xu G, Ren G, et al. Granulocyte-macrophage colony-stimulating factor (GM-CSF) and T-cell responses: what we do and don't know. Cell Res. 2006;16(2):126-33.

156. Anderson PM, Markovic SN, Sloan JA, Clawson ML, Wylam $\mathrm{M}$, Arndt CA, et al. Aerosol granulocyte macrophage-colony stimulating factor: a low toxicity, lung-specific biological therapy in patients with lung metastases. Clin Cancer Res. 1999;5(9):2316-23.

157. Dranoff G, Jaffee E, Lazenby A, Golumbek P, Levitsky H, Brose $\mathrm{K}$, et al. Vaccination with irradiated tumor cells engineered to secrete murine granulocyte-macrophage colony-stimulating factor stimulates potent, specific, and long-lasting anti-tumor immunity. Proc Natl Acad Sci. 1993;90(8):3539-43.

158. Kumar R, Yoneda J, Fidler IJ, Dong Z. GM-CSF-transduced B16 melanoma cells are highly susceptible to lysis by normal murine macrophages and poorly tumorigenic in immune-compromised mice. J Leukoc Biol. 1999;65(1):102-8.

159. Arndt CA, Koshkina NV, Inwards CY, Hawkins DS, Krailo MD, Villaluna D, et al. Inhaled granulocyte-macrophage colony stimulating factor for first pulmonary recurrence of osteosarcoma: effects on disease-free survival and immunomodulation. a report from the Children's Oncology Group. Clin Cancer Res. 2010;16(15):4024-30.

160. Okuno S, Petersen I, Shives T, Mahoney M, Haddock M, Sim F, et al. Chemotherapy, irradiation, and surgery for function- preserving curative therapy of primary extremity soft tissue sarcomas: initial treatment with I-MAP and inhalation GM-CSF during preoperative irradiation and postoperatively. Am J Clin Oncol. 2014. (Epub 30 Jan).

161. Strander H, Einhorn S. Effect of human leukocyte interferon on the growth of human osteosarcoma cells in tissue culture. Int $\mathbf{J}$ Cancer. 1977;19(4):468-73.

162. Bielack SS, Smeland S, Whelan J, Marina N, Hook J, Jovic G, et al. MAP plus maintenance pegylated interferon $\{$ alpha $\}-2 b$ (MAPIfn) versus MAP alone in patients with resectable highgrade osteosarcoma and good histologic response to preoperative MAP: first results of the EURAMOS-1 "good response" randomization. ASCO Meeting Abstracts. 2013;31(18 Suppl):LBA10504.

163. Fyfe G, Fisher RI, Rosenberg SA, Sznol M, Parkinson DR, Louie AC. Results of treatment of 255 patients with metastatic renal cell carcinoma who received high-dose recombinant interleukin-2 therapy. J Clin Oncol. 1995;13(3):688-96 (Epub 1995/03/01).

164. Guma SR, Lee DA, Ling Y, Gordon N, Kleinerman ES. Aerosol interleukin-2 induces natural killer cell proliferation in the lung and combination therapy improves the survival of mice with osteosarcoma lung metastasis. Pediatr Blood Cancer. 2014;61(8):1362-8.

165. Guma SR, Lee DA, Yu L, Gordon N, Hughes D, Stewart J, et al. Natural killer cell therapy and aerosol interleukin-2 for the treatment of osteosarcoma lung metastasis. Pediatr Blood Cancer. 2014;61(4):618-26.

166. Zhu L, McManus MM, Hughes DP. Understanding the biology of bone sarcoma from early initiating events through late events in metastasis and disease progression. Front Oncol. 2013;3:230 (Epub 2013/09/26).

167. Mortus JR, Zhang Y, Hughes DPM. developmental pathways hijacked by osteosarcoma. In: Kleinerman ES, editor. Current advances in osteosarcoma. New York: Springer Science and Business Media; 2014.

168. Xin ZF, Kim YK, Jung ST. Risedronate inhibits human osteosarcoma cell invasion. J Exp Clin Cancer Res. 2009;28:105 (Epub 2009/07/25).

169. Ferrari C, Benassi S, Ponticelli F, Gamberi G, Ragazzini P, Pazzaglia L, et al. Role of MMP-9 and its tissue inhibitor TIMP1 in human osteosarcoma: findings in 42 patients followed for 1-16 years. Acta Orthop Scand. 2004;75(4):487-91.

170. Liu B, Li G, Wang X, Liu Y. A furin inhibitor downregulates osteosarcoma cell migration by downregulating the expression levels of MT1-MMP via the Wnt signaling pathway. Oncol Lett. 2014;7(4):1033-8.

171. Dalal S, Berry AM, Cullinane CJ, Mangham DC, Grimer R, Lewis IJ, et al. Vascular endothelial growth factor: a therapeutic target for tumors of the Ewing's sarcoma family. Clin Cancer Res. 2005;11(6):2364-78 (Epub 2005/03/25).

172. Bajpai J, Sharma M, Sreenivas V, Kumar R, Gamnagatti S, Khan SA, et al. VEGF expression as a prognostic marker in osteosarcoma. Pediatr Blood Cancer. 2009;53(6):1035-9 (Epub 2009/07/22).

173. Zhang F, Yang Q, Meng F, Shi H, Li H, Liang Y, et al. Astrocyte elevated gene-1 interacts with beta-catenin and increases migration and invasion of colorectal carcinoma. Mol Carcinog. 2013;52(8):603-10 (Epub 2012/03/21).

174. Kreuter M, Paulussen M, Boeckeler J, Gerss J, Buerger H, Liebscher C, et al. Clinical significance of vascular endothelial growth factor-A expression in Ewing's sarcoma. Eur J Cancer. 2006;42(12):1904-11 (Epub 2006/07/11).

175. DuBois SG, Marina N, Glade-Bender J. Angiogenesis and vascular targeting in Ewing sarcoma: a review of preclinical and clinical data. Cancer. 2010;116(3):749-57 (Epub 2009/12/24). 
176. Glade Bender JL, Adamson PC, Reid JM, Xu L, Baruchel S, Shaked Y, et al. Phase I trial and pharmacokinetic study of bevacizumab in pediatric patients with refractory solid tumors: a Children's Oncology Group Study. J Clin Oncol. 2008;26(3):399-405 (Epub 2008/01/19).

177. Skubitz KM, Haddad PA. Combination of pegylated-liposomal doxorubicin (PLD) and bevacizumab (B) (PLD-B) in sarcoma (SAR). ASCO Meeting Abstracts. 2007;25(18 Suppl):20506.

178. Khanna C, Fan TM, Gorlick R, Helman LJ, Kleinerman ES, Adamson PC, et al. Toward a drug development path that targets metastatic progression in osteosarcoma. Clin Cancer Res. 2014;20(16):4200-9 (Epub 2014/05/08).

179. Anderson P, Subbiah V, Rohren E. Bone-seeking radiopharmaceuticals as targeted agents of osteosarcoma: samarium-153EDTMP and radium-223. In: Kleinerman MDES, editor. Current advances in osteosarcoma. Springer Cham Heidelberg New York Dordrecht London: Springer International Publishing; 2014. p. 291-304.

180. Turner DC, Navid F, Daw NC, Mao S, Wu J, Santana VM, et al. Population pharmacokinetics of bevacizumab in children with osteosarcoma: implications for dosing. Clin Cancer Res. 2014;20(10):2783-92 (Epub 2014/03/19).

181. Grignani G, Palmerini E, Ferraresi V, D'Ambrosio L, Bertulli R, Asaftei SD, et al. Sorafenib and everolimus for patients with unresectable high-grade osteosarcoma progressing after standard treatment: a non-randomised phase 2 clinical trial. Lancet Oncol. 2015;16(1):98-107 (Epub 2014/12/17).

182. Choy E, Butrynski JE, Harmon DC, Morgan JA, George S, Wagner AJ, et al. Phase II study of olaparib in patients with refractory Ewing sarcoma following failure of standard chemotherapy. BMC Cancer. 2014;14:813 (Epub 2014/11/07).

183. Navid F, Sondel PM, Barfield R, Shulkin BL, Kaufman RA, Allay JA, et al. Phase I trial of a novel anti-GD2 monoclonal antibody, Hu14.18K322A, designed to decrease toxicity in children with refractory or recurrent neuroblastoma. J Clin Oncol. 2014;32(14):1445-52 (Epub 2014/04/09). 